\title{
Greenhouse tomato production with electricity generation by roof-mounted flexible solar panels
}

\author{
Raúl Ureña-Sánchez, Ángel Jesús Callejón-Ferre*, José Pérez-Alonso, Ángel Carreño-Ortega
}

University of Almería - Depto. de Ingeniería Rural, Ctra. Sacramento s/n., La Cañada de San Urbano - 04120 Almería - Spain

*Corresponding author <acallejo@ual.es>

Edited by: José Euclides Stipp Paterniani

\begin{abstract}
The integration of renewable energy sources into greenhouse crop production in southeastern Spain could provide extra income for growers. Wind energy could be captured by small to medium-sized wind turbines, gas could be produced from biomass, and solar energy could be gathered by solar panels. The aim of this study was to examine the effect of flexible solar panels, mounted on top of a greenhouse for electricity production, on yield and fruit quality of tomatoes (Solanum lycopersycum L., cv Daniela). This study was undertaken in a commercial raspa y amagado greenhouse, typical of the Almería region (Spain). Tomato plantlets were planted at a density of 0.75 plants $\mathrm{m}^{-2}$. The flexible solar panels were mounted on two parts of the roof in different arrangements (T1 and T2), each blacking out $9.8 \%$ of its surface area. A control area (TO arrangement) was fitted with no panels. No difference was found in terms of total or marketable production under these three arrangements, although fruit mean mass and maximum diameter of T0 were significantly greater than T1 and T2. Fruit in T0 matured earlier with more intense color compared with those in T1 and T2. However, these differences had no effect on price as the tomatoes produced under three conditions fell into the same commercial class (G class; diameter $67-81 \mathrm{~mm}$ ). Solar panels covering $9.8 \%$ roof area of the greenhouse did not affect yield and price of tomatoes despite of their negative effect on fruit size and color.
\end{abstract}

Keywords: Solanum lycopersycum L., shading, total production, renewable energy, fruit quality

\section{Introduction}

The integration of renewable energy sources into greenhouse crop production in southeastern Spain could provide extra income for growers. Wind energy could be captured by small to medium-sized wind turbines, gas could be produced from biomass, and solar energy could be gathered by solar panels (Callejón-Ferre et al., 2011). Given the strong global solar radiation that falls in Almería (Spain), and the recent technological advances that have reduced the cost of producing solar energy, the installation of flexible solar panels on greenhouse roofs is an interesting proposition for growers (Varun et al., 2009).

The Almería region has about 27,000 ha of greenhouses (Callejón-Ferre et al., 2010), whose roofs could provide a huge area where solar panels might be mounted. However, there is concern regarding the impact of such solar panels on crop yield and fruit quality. Crop yield is linearly related to the amount of solar radiation reaching the plants, although fruit mass falls linearly with increasing temperature after the optimum temperature $\left(18^{\circ} \mathrm{C}\right)$ is surpassed (Newton et al., 1999). Yields are also affected, since the fruits produced are smaller (Cockshull et al., 1992). Commercial production of tomatoes (Solanum lycopersycum L.) in shaded greenhouses may also be affected by a higher incidence of blossom end rot due to the maintenance of a higher relative humidity. Although total production may not be affected this can lead to significant reductions in marketable production (Medrano et al., 2005).
This study aimed to determine the effect of shading caused by flexible solar panels, mounted on the roof of a greenhouse, on the production and quality of $\mathrm{cv}$. Daniela tomatoes grown within.

\section{Materials and Methods}

Experimental greenhouse and crop - This study was performed in a "raspa y amagado" greenhouse (Figures 1 and 2) occupying an area of 1,024 (32 $\times 32) \mathrm{m}^{2}$ in Almería $\left(36^{\circ} 52^{\prime} \mathrm{N}, 2^{\circ} 17^{\prime} \mathrm{W}, 98 \mathrm{~m}\right.$ a.s.1.). The orientation of the greenhouse can be seen in Figure 1. The greenhouse cover was made of new, co-extruded, three-layer polyethylene $(200 \mu \mathrm{m}$ thick; light transmittance $80 \%$ in the 400-800 $\mathrm{nm}$ range under laboratory conditions). Ventilation was provided by manually opened front windows and automatic lateral and roof windows depending on temperature and relative humidity inside the greenhouse.

Fertigation was provided by a drip system. The growth substrate was a sand-covered soil (a system typically used in Almería) consisting of a "sandwich" formed by $20-30 \mathrm{~cm}$ of fertile soil, a 1 to $3 \mathrm{~cm}$ layer of manure on top, and above that a layer of silica sand some 8-12 $\mathrm{cm}$ deep (Figure 2). The experimental crop was tomato cv. Daniela (the most widely grown cultivar in Almeria). Plantlets were transplanted into the greenhouse on $15^{\text {th }}$ September 2009 (spacing 0.5 m, distance between rows $1.5 \mathrm{~m})$. The end of marketable fruit production was $5^{\text {th }}$ May 2010. 
Treatments, experimental design and solar panels - The experimental design was a randomised block with three treatments (T0, T1, T2) and four replicates. Treatments were separated by vertical polyethylene walls. Each treatment was defined according to the type of shading caused by the flexible solar panels installed on the greenhouse roof (Figures 1 and 2). In T1, twelve flexible PV1 solar panels were installed, and in T2 six PV2 panels were installed (Table 1, Figures 1 and 2). The PV1 panels were flexible FUJI FPV 1096 panels (Fuji Electric Systems Co., Ltd., Japan); the PV2 type consisted of two FUJI FPV 1096 panels joined together (Figures 1 and 2, Table 1). The To treatment, i.e., the control, involved no

Table 1 - Specifications of the solar panels and the DC/AC converter system.

\begin{tabular}{lccc}
\hline \multicolumn{2}{c}{ SOLAR PANELS } & \multicolumn{2}{c}{ AC/DC CONVERTER } \\
\hline Name & FUJI TPV 1096 & Name & SMA SB 2500 \\
Type & a-Si thin film & AC Power(max) & 2300 W \\
Open Circuit Voltage & $429 \mathrm{~V}$ & AC Voltage & $220-240 \mathrm{VAC}$ \\
Short circuit Current & $0.390 \mathrm{~A}$ & Frequency & $50-60 \mathrm{~Hz}$ \\
Nominal $^{*}$ Voltage & $319 \mathrm{~V}$ & & \\
Nominal Current & $0.288 \mathrm{~A}$ & & \\
Nominal Power & $92 \mathrm{~W}$ & & \\
Area & $1.567 \mathrm{~m}^{2}$ & & \\
Weight & $1.4 \mathrm{~kg}$ & & \\
\hline
\end{tabular}

shading provided by solar panels (Figure 1). The T1 and T2 test zones each had a surface area of $192 \mathrm{~m}^{2}(16 \times 12$ $\mathrm{m})$, while the area of the T0 treatment was $544 \mathrm{~m}^{2}(32$ $\times 17.0 \mathrm{~m}$ ). The solar panels were connected in parallel

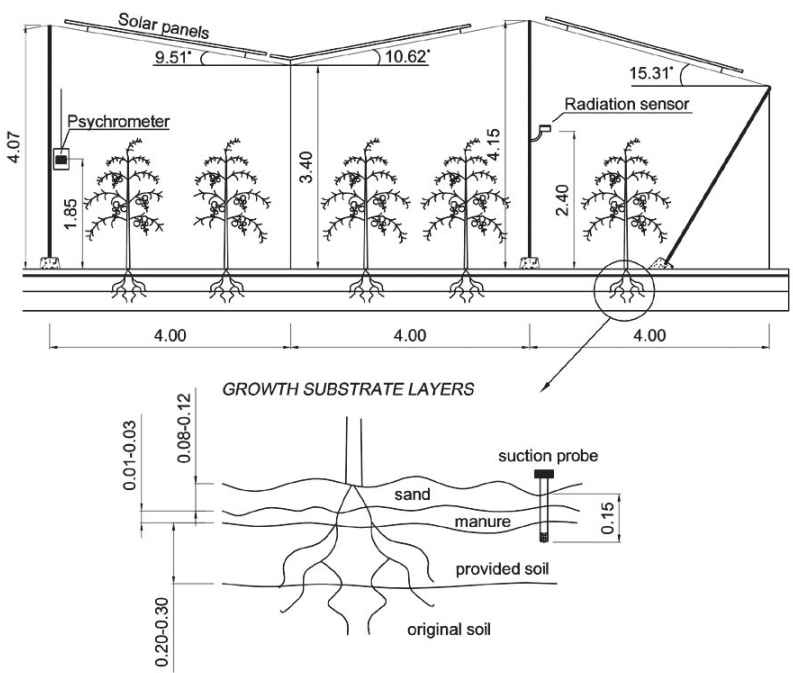

Figure 2 - Section of the raspa y amagado greenhouse and of the growth substrate used in the present work. The arrangements of the flexible solar panels on the greenhouse roof are also shown (not to scale).
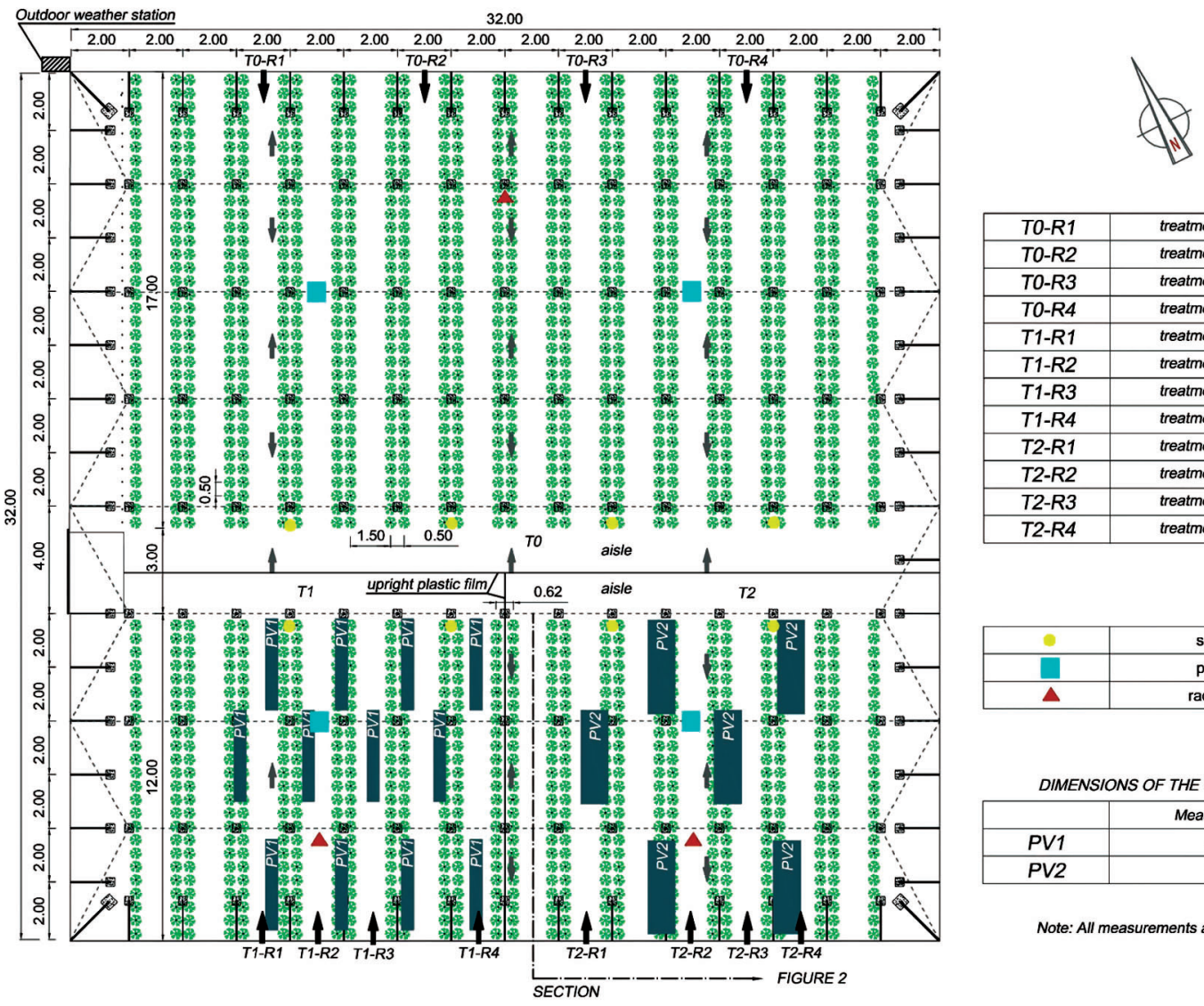

\begin{tabular}{|c|c|}
\hline$T 0-R 1$ & treatment T0 replicate $R 1$ \\
\hline$T 0-R 2$ & treatment T0 replicate $R 2$ \\
\hline$T 0-R 3$ & treatment T0 replicate $R 3$ \\
\hline$T 0-R 4$ & treatment T0 replicate $R 4$ \\
\hline$T 1-R 1$ & treatment $T 1$ replicate $R 1$ \\
\hline$T 1-R 2$ & treatment $T 1$ replicate $R 2$ \\
\hline$T 1-R 3$ & treatment $T 1$ replicate $R 3$ \\
\hline$T 1-R 4$ & treatment $T 1$ replicate $R 4$ \\
\hline$T 2-R 1$ & treatment $T 2$ replicate $R 1$ \\
\hline$T 2-R 2$ & treatment $T 2$ replicate $R 2$ \\
\hline$T 2-R 3$ & treatment $T 2$ replicate $R 3$ \\
\hline$T 2-R 4$ & treatment $T 2$ replicate $R 4$ \\
\hline \multicolumn{2}{|c}{} \\
\multicolumn{2}{|c}{} \\
\hline & \\
\hline & suction probe \\
\hline & psychrometer \\
\hline & radiation sensor \\
\hline
\end{tabular}

DIMENSIONS OF THE SOLAR PANELS

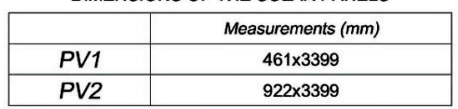

Note: All measurements are in meters

Figure 1 - Experimental design. 
and fed into the electricity grid via an SB2500 DC/AC converter (SMA Solar Technology AG, Germany).

The roof blacking afforded by each solar panel in $\mathrm{T} 1$ was $1.567 \mathrm{~m}^{2}(0.461 \times 3.399 \mathrm{~m})$ while in $\mathrm{T} 2$, with the 'double' PV2 panels, it was $3.134 \mathrm{~m}^{2}(0.922 \times 3.399 \mathrm{~m})$; in total the panels therefore provided $18.80 \mathrm{~m}^{2}$ of roof blacking in both of these treatments. Since $192 \mathrm{~m}^{2}$ of roof were given over for the $\mathrm{T} 1$ and $\mathrm{T} 2$ experiments (Figure 1), each of these treatments blacked out $9.8 \%$ of the roof. The energy consumed by the greenhouse (e.g., for the automatic opening and closing of the windows and the running of the fertigation pump etc.) was recorded using a CIRCUTOR MK-30-DC electricity meter (CIRCUTOR S.A., Viladecavalls, Barcelona, Spain).

Tomato production was monitored in plots of 35 $\mathrm{m}^{2}$ in $\mathrm{T} 0$, and $25 \mathrm{~m}^{2}$ in $\mathrm{T} 1$ and $\mathrm{T} 2$, avoiding the border effect. Seventy plants were examined in T0, 50 in T1 and 50 in T2 in each replicate. Total and marketable productions were determined for each plot. Marketable production was defined as the production left over after ruling out fruits showing blossom end rot and those that were immature, split, deformed or outside the marketable size range (Table 2 ).

Variables measured - The EC and $\mathrm{pH}$ of the growth substrate were measured using a Hanna 9811 EC-pHTDS meter (Hanna Instruments S. L., Eibar, Guipúzcoa, Spain) with a resolution of $0.01 \mathrm{dS} \mathrm{m}^{-1}$. Growth substrate solution was obtained using $15 \mathrm{~cm}$ suction probes (Himarcan, El Ejido, Almería, Spain); three samples were taken for each treatment. Fruit quality was assessed on each harvest day (see below) for each plot ( $\mathrm{n}=25$ fruits for each replicate) in terms of mean fruit mass, pulp firmness, colour, maximum diameter, soluble solids ( ${ }^{\circ}$ Brix) and $\mathrm{pH}$. Total production was determined for each plot using an EKS Premium digital balance (EKS, Beijing, China) with a precision of $10 \mathrm{~g}$. Fruit mass was determined using a BEC Engineering electronic balance with a resolution of $1 \mathrm{~g}$. Pulp firmness was determined using a PCE-PTR 200 digital penetrometer (PCE IBERICA S.L., Tobarra, Albacete, Spain) equipped with a standard $1.0 \mathrm{~cm}^{2}$ probe operated at a constant penetration speed. This penetrometer has the capacity to measure forces between 0 and $13 \mathrm{~kg} \mathrm{~cm}^{-2}$ with a resolution of $0.01 \mathrm{~kg}$. Each fruit was examined in three places along the equatorial zone after removing approximately $2 \mathrm{~cm}^{2}$ (skin) for each measurement. ${ }^{\circ}$ Brix values were determined using

Table 2 - Commercial classes of tomato according to the DOCE (2001) and Camacho-Ferre et al. (1998) classification systems.

\begin{tabular}{cc} 
DOCE class & Camacho-Ferre et al. class \\
$35-39 \mathrm{~mm}$ & - \\
$40-46 \mathrm{~mm}$ & MMM \\
$47-56 \mathrm{~mm}$ & $\mathrm{MM}$ \\
$57-66 \mathrm{~mm}$ & $\mathrm{M}$ \\
$67-81 \mathrm{~mm}$ & $\mathrm{G}$ \\
$82-101 \mathrm{~mm}$ & $\mathrm{GG}$ \\
$>102 \mathrm{~mm}$ & $\mathrm{GGG}$ \\
\hline
\end{tabular}

an ATAGO PR-101 $\alpha$ digital refractometer (ATAGO CO., LTD, Tokyo, Japan) with a resolution of 0.1 . Fruit acidity was determined using a CRISON MM 40 pH meter (CRISON INSTRUMENTS S.A., Alella, Barcelona, Spain) with a resolution of 0.01 units. Fruit hardness was determined on a scale of 10-100 using a Durofel DFT100 durometer (AGRO-TECHNOLOGIE, Forges Les Eaux, Haute Normandie, France) with a resolution of 1 unit. Fruit maximum diameter $(\mathrm{mm})$ was determined using a loop calibrator. Fruit colour was measured on a graded colour scale (1-10) with a resolution of 1 unit.

Internal and external (roof-incident) solar radiation was measured using Fotodiodo linear radiation sensors (Nutricontrol S.L., Cartagena, Murcia, Spain) with a range $0-2000 \mathrm{~W} \mathrm{~m}^{-2}$ and error of $2 \%$. Internal and external temperature and relative humidity were measured using a Bulbo model temperature/relative humidity probe (Nutricontrol S.L., Cartagena, Murcia, Spain) with a resolution $0.1{ }^{\circ} \mathrm{C}$ and an error of $\pm 0.3{ }^{\circ} \mathrm{C}$ for temperature and $\pm 2 \%$ for relative humidity over a 0-100\% range (Nutricontrol S.L., Cartagena, Murcia, Spain). Inside the greenhouse, the latter sensor was protected from direct sunlight and located $1.85 \mathrm{~m}$ above the growth substrate (Figure 1). External rainfall was obtained from the University of Almería experimental weather station (situated some $200 \mathrm{~m}$ from the experimental greenhouse) using a Geonica model 52202 pluviometer (Geonica S.A., Madrid, Spain) with a $200 \mathrm{~cm}^{2}$ collecting surface and a resolution of $0.1 \mathrm{~mm}$ per tip and an error of $2 \%$ up to 25 $\mathrm{mm} \mathrm{h}^{-1}$ or $3 \%$ up to $50 \mathrm{~mm} \mathrm{~h}^{-1}$.

Light transmission (\%) (LT) through the polyethylene cover under the experimental conditions of the study was calculated using Equation (1) (Buriol et al., 1995):

$L T=\frac{K_{i}}{K_{o}} \times 100$

where $\mathrm{K}_{\mathrm{i}}\left(\mathrm{W} \mathrm{m}^{-2}\right)$ and $\mathrm{K}_{\mathrm{o}}\left(\mathrm{W} \mathrm{m}^{-2}\right)$ are the flow densities of the internal and external solar radiation respectively.

Electrical conductivity and $\mathrm{pH}$ were measured 27 times: at $29,37,44,51,58,65,72,79,87,94,100,106$, $114,121,127,133,139,147,155,162,169,176,183$, 190, 197, 204 and 212 days after transplantation (dat).

Total production, marketable production, fruit mass and maximum fruit diameter were measured nine times, at 125, 139, 149, 162, 170, 177, 184, 202 and 212 days. Fruit commercial quality was measured five times, at $149,162,177,184$ and 202 days using the DOCE (2001) and Camacho-Ferre et al. (1998) classification systems (Table 2).

Statistical data analysis - The results (growth substrate $\mathrm{EC}$ and $\mathrm{pH}$, fruit mass, pulp firmness, maximum diameter, ${ }^{\circ}$ Brix, $\mathrm{pH}$, hardness and colour, total production and marketable production) were analysed by ANOVA after checking the data for normality and homoscedasticity. Significance was set at $p<0.05$. Calculations were performed using XLSTAT 2009 software for Windows. 
Cost analysis - The cost of the solar panels systems was calculated, as were the savings made through energy self-provision (i.e., energy produced by the greenhouse), and the income from the sale of the remaining energy to the electricity grid.

\section{Results}

Energy production and cost analysis - The energy production of the solar panels was $2766 \mathrm{~kW} \mathrm{~h}$ crop-cycle ${ }^{-1}$ in both T1 and T2. The cost of the solar panel system was $373.43 € \mathrm{~m}^{-2}$ in both $\mathrm{T} 1$ and $\mathrm{T} 2$. The consumption of selfproduced energy by the greenhouse during the growing cycle was $768 \mathrm{~kW} \mathrm{~h}$ in both T1 and T2. The cost of $1 \mathrm{~kW}$ h grid-supplied electricity was $0.125 €$. Thus, the savings made by the consumption of self-produced energy during the growth cycle was $96.13 €$. Finally, since Spain's Government subsidises the production of photovoltaic energy at a price of $0.32 € \mathrm{~kW}^{-1} \mathrm{~h}^{-1}$, the rest of the energy produced over the growth cycle $(2766-768=1998 \mathrm{~kW}$ h) provided an income of $639.53 €$.

Effect of treatments on environmental conditions - The EC of the growth substrate solution (Figure 3) changed over the growth period in the different treatments. Except for during the first 44 days, the EC of
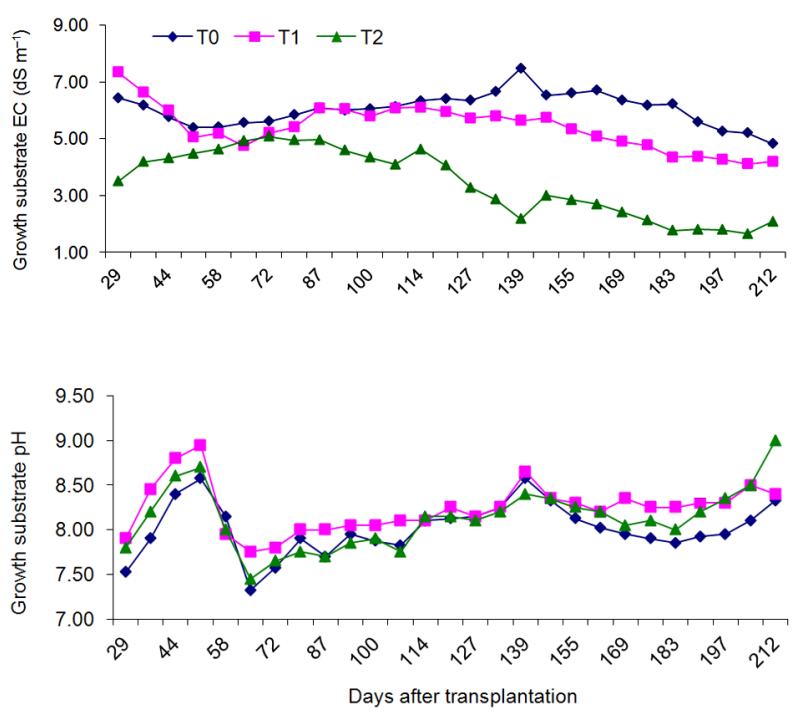

Figure 3 - Growth substrate electrical conductivity (EC) and pH in the treatments over time. the growth substrate was higher in T0 compared to $\mathrm{T} 1$, which in turn was higher than that recorded in T2 (Figure 3). The EC for T2 was always below that of T0. The $\mathrm{pH}$ of the growth substrate (Figure 3) was similar in all treatments, fluctuating slightly over the crop cycle.

Table 3 shows the mean light transmission through the polyethylene cover in each treatment (individual values determined using Equation [1]). The difference of light transmission between the T0 treatment and $\mathrm{T} 1$ is similar than the difference between $\mathrm{T} 0$ and $\mathrm{T} 2$ along the crop cycle (Table 3).

Figure 4 shows the daily averages for temperature, relative humidity and radiation, both outside the green-
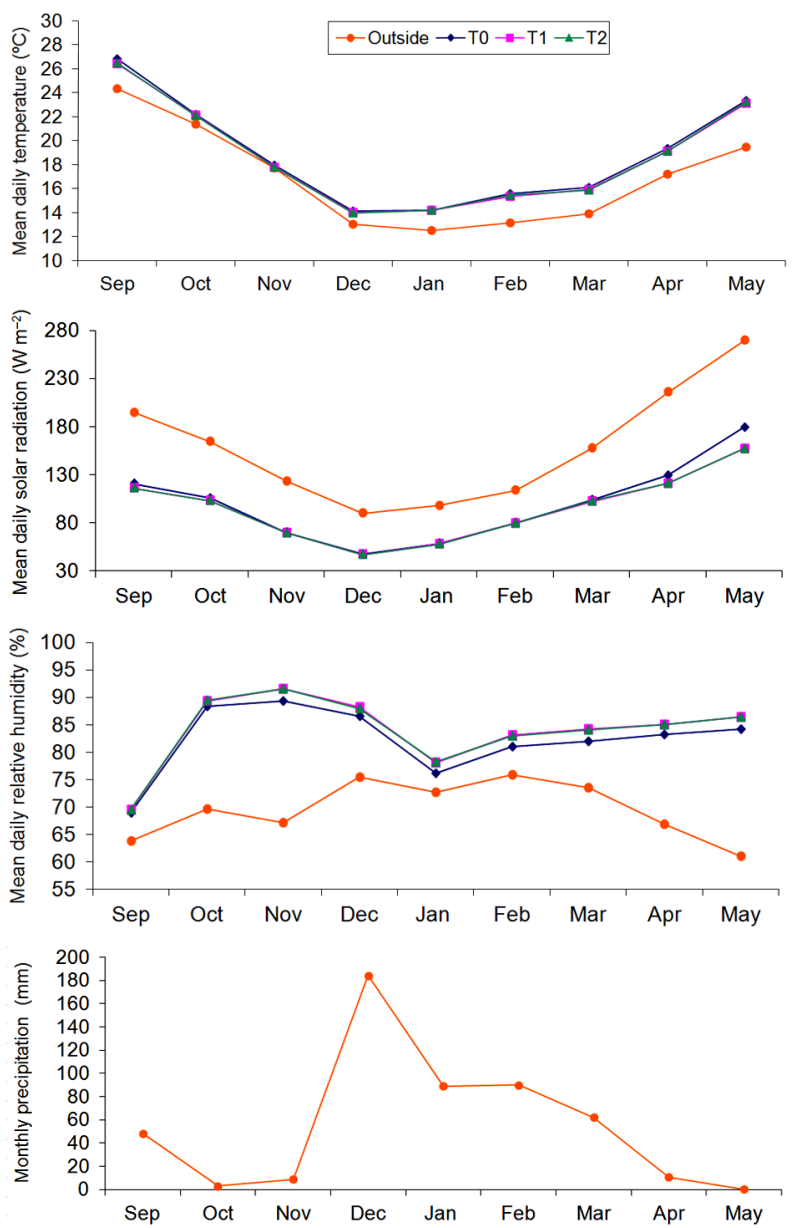

Figure 4 - Mean daily temperature, relative humidity, radiation and monthly precipitation.

Table 3 - Mean light transmission though the polyethylene cover in each treatment.

\begin{tabular}{|c|c|c|c|c|c|c|c|c|c|}
\hline Light transmission (F) & Sep & Oct & Nov & Dec & Jan & Feb & Mar & Apr & May \\
\hline $\mathrm{F}_{\mathrm{TO}}=\mathrm{K}_{\mathrm{TTO}} \mathrm{K}_{\mathrm{o}}^{-1} 100$ & 61.96 & 64.11 & 56.70 & 52.50 & 59.44 & 70.21 & 65.86 & 60.07 & 66.58 \\
\hline $\mathrm{F}_{\mathrm{T} 1}=\mathrm{K}_{\mathrm{TT} 1} \mathrm{~K}_{0}^{-1} 100$ & 59.54 & 62.59 & 56.53 & 52.06 & 58.94 & 70.00 & 64.96 & 56.16 & 58.23 \\
\hline $\mathrm{F}_{\mathrm{T} 2}=\mathrm{K}_{\mathrm{iT} 2} \mathrm{~K}_{\mathrm{o}}^{-1} 100$ & 59.52 & 62.60 & 56.55 & 52.11 & 58.89 & 69.95 & 64.98 & 56.13 & 58.21 \\
\hline $\mathrm{F}_{\mathrm{T} 0}-\mathrm{F}_{\mathrm{T} 1}(\%)$ & 2.42 & 1.53 & 0.17 & 0.43 & 0.50 & 0.21 & 0.90 & 3.91 & 8.34 \\
\hline $\mathrm{F}_{\mathrm{T} 0}-\mathrm{F}_{\mathrm{T} 2}(\%)$ & 2.44 & 1.51 & 0.15 & 0.39 & 0.55 & 0.26 & 0.88 & 3.94 & 8.36 \\
\hline
\end{tabular}


house and in each of the three interior treatment areas. It also shows the monthly rainfall data. The mean daily temperature for the T0 treatment was slightly higher than that for the T1 and T2 treatments in Sep., Oct., Dec., Apr., May and Jun.. No differences were seen between the $\mathrm{T} 1$ and $\mathrm{T} 2$ treatments. In addition, mean daily relative humidity for the T0 treatment was lower than in the T1 and T2 treatments in autumn and winter (Oct.Feb.). No differences were seen between T1 and T2. On the other hand, mean daily radiation for the T0 treatment was greater than in $\mathrm{T} 1$ or $\mathrm{T} 2$ for the entire study period (Figure 4), the difference increasing in the months with the greatest amount of sunlight (Sep., Oct., Apr., May and Jun.). No differences were seen between T1 and T2. During the time of study the average of monthly precipitation was higher than the common monthly precipitation of Spanish southeast (especially from Dec. to Mar.).

Effect of treatments on yield and fruit quality The mean fruit mass was greater in T0 than in T1 or T2 on all harvest days except for 149 days (Figure 5). The mean maximum fruit diameter was greater in T0 than in T1 or T2 on all harvest days except for 149 and 177 days (Figure 5). In T0, fruit hardness showed a decreasing trend over time, with mean values ranging from 90 at 149 days to 81 at 202 days. In T1 and T2 fruit hardness was more irregular over time (Figure 5). Pulp firmness at the first three harvests $(149,162$ and 177 days) was lower $(p<0.05)$ in $\mathrm{T} 0$ than $\mathrm{T} 1$ and T2, while at 184 and 202 days the T0 values exceeded those for T1 and/or T2 (Figure 5). The trend for fruit colour (Figure 5) was similar in all treatments with fruits becoming slightly redder over the growth cycle, although the T0 fruits were generally redder than those of $\mathrm{T} 1$ and $\mathrm{T} 2$.
All three treatments showed apparently similar behaviour with respect to fruit $\mathrm{pH}$ (Figure 5). The maximum recorded was 4.03 at 162 days in all treatments. However, differences $(p<0.05)$ were seen between T0 and $\mathrm{T} 1$, although not between $\mathrm{T} 2$ and T0/T1 (Table 4). The minimum $\mathrm{pH}$ recorded was 3.83 in $\mathrm{T} 1$ at 177 days.

T0, T1 and T2 showed apparently similar ${ }^{\circ}$ Brix values (Figure 5), which tended to rise over the study period. Nonetheless differences were observed $(p<0.05)$ between $\mathrm{T} 1$ and $\mathrm{T} 2$, although not between $\mathrm{T} 0$ and $\mathrm{T} 1$, nor between T0 and T2 (Table 4). No differences were seen between the treatments in terms of pulp firmness (Table 4). No differences were found between the treatments in fruit hardness. No differences were observed between $\mathrm{T} 1$ and $\mathrm{T} 2$ in terms of fruit colour, although differences $(p<0.05)$ were detected between both these last treatments and T0 (Table 4).

The cumulative total production in $\mathrm{T} 0$ at 125 days was $1.27 \mathrm{~kg} \mathrm{~m}^{-2}$ rising to $11.6 \mathrm{~kg} \mathrm{~m}^{-2}$ by 212 days. In $\mathrm{T} 1$ these figures were $1.22 \mathrm{~kg} \mathrm{~m}^{-2}$ and $10.73 \mathrm{~kg} \mathrm{~m}^{-2}$, and in T2 they were $1.74 \mathrm{~kg} \mathrm{~m}^{-2}$ and $12.18 \mathrm{~kg} \mathrm{~m}^{-2}$ (Figure 5). In $\mathrm{T} 0$, cumulative marketable production on these same dates was $1.04 \mathrm{~kg} \mathrm{~m}^{-2}$ and $9.13 \mathrm{~kg} \mathrm{~m}^{-2}$, in $\mathrm{T} 10.98 \mathrm{~kg} \mathrm{~m}^{-2}$ and $8.65 \mathrm{~kg} \mathrm{~m}^{-2}$, and in T2 $1.43 \mathrm{~kg} \mathrm{~m}^{-2}$ and $9.68 \mathrm{~kg} \mathrm{~m}^{-2}$ (Figure 5). Marketable production was around $20 \%$ low-

\begin{tabular}{llllll}
\multicolumn{6}{l}{ Table 4 - Fruit quality in the three treatments. } \\
\hline \multicolumn{7}{l}{ Treatments } & ${ }^{\circ}$ Brix & Fruit pH & Pulp firmness & $\begin{array}{c}\text { Hardness } \\
(10-100)\end{array}$ & $\begin{array}{c}\text { Colour } \\
(1-10)\end{array}$ \\
\hline T0 & $5.30 \mathrm{ab}$ & $3.98 \mathrm{~b}$ & $3.08 \mathrm{a}$ & $86.24 \mathrm{a}$ & $6.97 \mathrm{~b}$ \\
T1 & $5.25 \mathrm{a}$ & $3.96 \mathrm{a}$ & $3.12 \mathrm{a}$ & $85.78 \mathrm{a}$ & $6.77 \mathrm{a}$ \\
T2 & $5.47 \mathrm{~b}$ & $3.97 \mathrm{ab}$ & $3.12 \mathrm{a}$ & $85.51 \mathrm{a}$ & $6.79 \mathrm{a}$ \\
\hline
\end{tabular}

Numbers with different letters in the column are different $(p<0.05$; Bonferroni test).
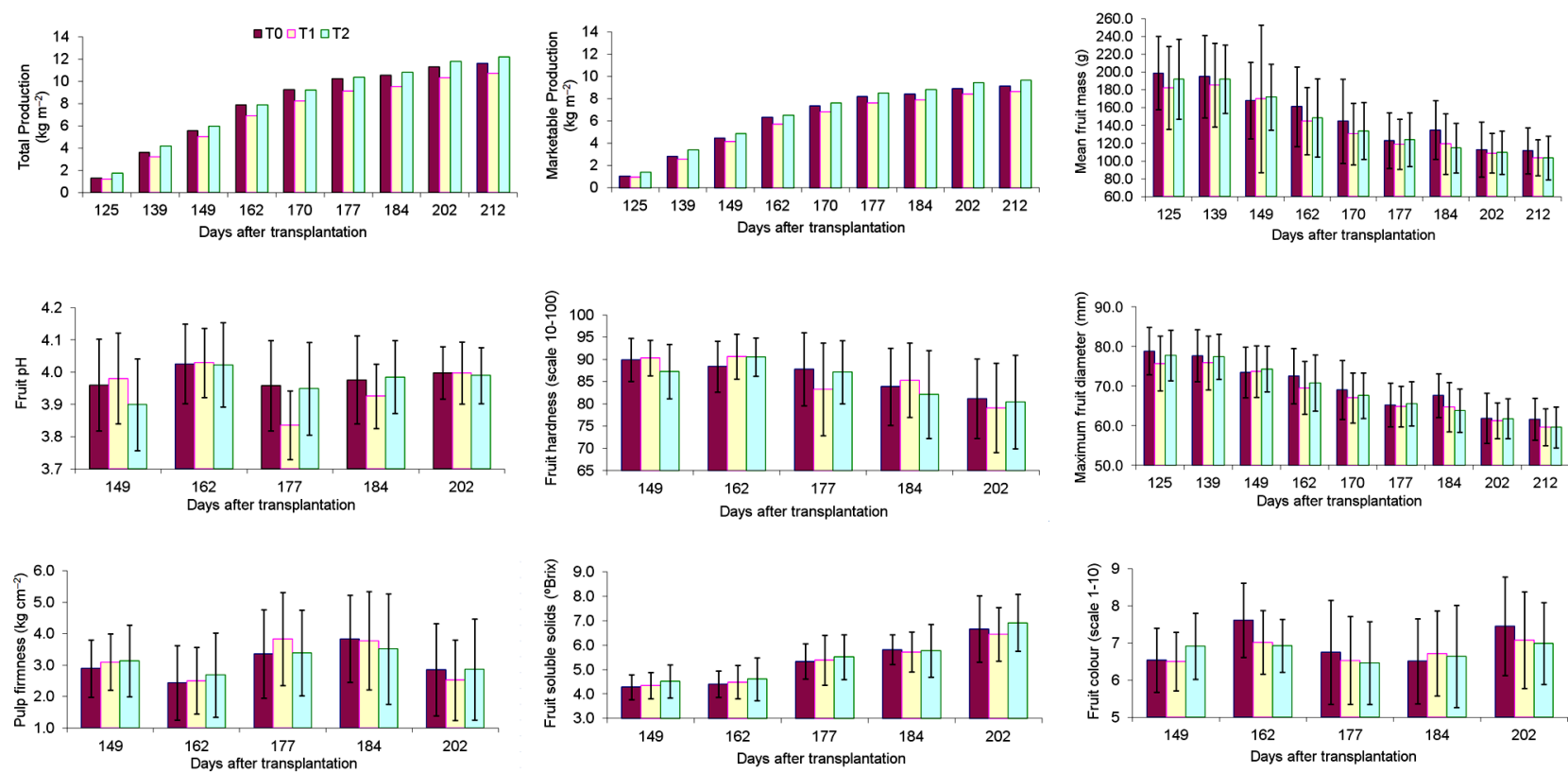

Figure 5 - Production and fruit quality in the treatments (T0, T1 and T2) over time with standard deviation. 
Table 5 - Total production, marketable production, mean fruit mass, maximum fruit diameter, electrical conductivity (EC) of the soil solution and $\mathrm{pH}$ for three treatments.

\begin{tabular}{lcccccc}
\hline Treatments & Marketable production & Total production & Mean fruit mass & Maximum fruit diameter & Soil EC & Soil pH \\
\cline { 2 - 3 } & $9.15 \mathrm{a}$ & $11.62 \mathrm{a}$ & $150.09 \mathrm{~b}$ & $69.73 \mathrm{~b}$ & $6.04 \mathrm{~b}$ & $8.01 \mathrm{a}$ \\
T0 & $8.64 \mathrm{a}$ & $10.74 \mathrm{a}$ & $141.13 \mathrm{a}$ & $68.08 \mathrm{a}$ & $5.40 \mathrm{~b}$ & $8.24 \mathrm{~b}$ \\
T1 & $9.69 \mathrm{a}$ & $12.18 \mathrm{a}$ & $143.42 \mathrm{a}$ & $68.70 \mathrm{a}$ & $3.45 \mathrm{a}$ & $8.12 \mathrm{ab}$ \\
\hline
\end{tabular}

Numbers with different letters in the column are different ( $p<0.05$; Bonferroni test).

er than total production in all treatments (with no significant differences between treatments). No differences were seen in terms of mean fruit mass or maximum fruit diameter between $\mathrm{T} 1$ and $\mathrm{T} 2$, although differences between T1/T2 and T0 were significant (Table 5).

No differences were seen between $\mathrm{T} 0$ and $\mathrm{T} 1$ in terms of growth substrate EC. Differences were seen, however, between T0/T1 and T2. Differences were also seen between the T0 and T1/T2 in terms of growth $\mathrm{pH}$ (Table 5).

\section{Discussion}

The year 2009 was very rainy and the relative humidity levels reached were unusually high (Figure 4). High humidity (Figure 4) is favourable to fungal growth, and may have been responsible for the difference between total and marketable production (Kittas et al., 2003).

The small reduction in light transmitted through the polythene cover (Table 3 and Figure 4) in T1 and T2 compared to T0 was a consequence of the $9.8 \%$ blacking caused by the solar panels. This led to a small reduction in the amount of solar radiation reaching the crop (Figure 4), but this did not affect total or marketable production. At different times of year, slightly different amounts of solar radiation reached the plants in $\mathrm{T} 1$ and $\mathrm{T} 2$, perhaps due to the arrangement of the panels in these treatments (Table 3). The increase in natural solar radiation and temperature from early February (first harvest) to May (last harvest) (Figure 4), and the consequent increase in their values inside the greenhouse, may have caused the mean fruit mass and maximum fruit diameter to fall over this time period. This agrees with that reported by Newton et al. (1999).

High soil EC values can reduce total and marketable production, fruit maximum diameter and mean fruit mass, but increase fruit firmness, hardness and improve taste (determined by the relationship between ${ }^{\circ}$ Brix and pH) (Awanng et al., 1993; Petersen et al., 1998; Lorenzo et al., 2006; Callejón-Ferre et al., 2009). It might be expected that, given the significantly lower EC values recorded in $\mathrm{T} 2$, total and marketable production might be greater than in T0 and T1 (Table 4). However, no differences were seen in these respects. Differences between the treatments were seen in terms of mean fruit mass and maximum diameter, with the physically largest fruits obtained in the T0 treatment, in which the EC was actually the highest (Table 4). Thus, the latter results may have been more the outcome of the lack of shading than any effect of EC (Cockshull et al., 1992; Papadopoulos and Parajasingham, 1997; Marcelis et al., 2006). The lower EC in T2 might be explained by differences between the treatments in the depth of the different growth substrate layers (Figure 2) plus possible differences in the speed of mineralisation of the manure layer. Together, these variations may have rendered fewer ions available in T2 (Castilla, 2005).

The smaller fruits of T1 and T2 did not affect the final price that could be demanded for the crop since this depends on the commercial classification scale for tomatoes (Table 2), and the fruits from all three treatments fell into the same commercial class. At the early harvests (at 125, 139, 149, 162 and 170 days) the fruits of T0, T1 and T2 all fell into Camacho-Ferre et al. (1998) class $\mathrm{G}$ while at 177, 184, 202 and 212 days they fell into class $M$, with the sole exception of 184 day when the T0 fruits fell into class $\mathrm{G}$ (Table 2).

Differences were seen in fruit $\mathrm{pH}$ between the $\mathrm{T} 0$ and $\mathrm{T} 1$ treatments, although none were seen between $\mathrm{T} 2$ and $\mathrm{T} 0 / \mathrm{T} 1$; even so, these maximum difference was only 0.02 . Differences were also seen in the ${ }^{\circ}$ Brix value between $\mathrm{T} 1$ and $\mathrm{T} 2$, but not between $\mathrm{T} 0$ and $\mathrm{T} 1 / \mathrm{T} 2$ (maximum difference 0.18). These small differences were detected because of the very large sample size (1500 data from 149-202 days). They would not be appreciable, however, to consumers.

T0 tomatoes had the most intense colour and the softest, the T1 tomatoes had less intense colour and greater hardness than of $\mathrm{T} 2$, and the $\mathrm{T} 2$ tomatoes had intermediate values of colour and hardness. Thus, although the T0 fruits were larger, their colour was of poorer quality than those of $\mathrm{T} 1$ and $\mathrm{T} 2$ with respect to their transport and eventual chances of being sold to consumers (Table 4).

Given the $639.53 €$ income generated by the solar panel systems, the time required to return the investment capital would be about 18 years (as long as the subsidy provided by the Spanish government continues), although it might be shorter if interested growers could purchase the many panels they would need at a lower cost.

\section{Conclusions}

Solar panels placed in two different arrangements on the roof of a raspa y amagado greenhouse in 
Almería, each blacking $9.8 \%$ of the corresponding roof surface, did not negatively affect the marketable production or the pulp firmness of cv. Daniela tomatoes. Differences were seen between the control and treatments with respect to mean fruit mass and maximum fruit diameter, but since all the fruits produced fell into the same commercial class the price that could be demanded was not affected. Thus, growers could install flexible solar panels affording $9.8 \%$ blacking, and in different arrangements, on tomato greenhouses as a means of generating electricity/extra income.

\section{Acknowledgements}

To the Consejería de Innovación, Ciencia y Empresa de la Junta de Andalucía (Spain) and the Ministerio de Ciencia e Innovación del Gobierno de España as well as to the Fondos Europeos de Desarrollo Regional (FEDER) for financing the present work through the research projects P08-AGR-04231 and AGL2006-11186 respectively.

\section{References}

Awanng, Y.B.; Atherton, J.G.; Taylor, A.J. 1993. Salinity effects on strawberry plants grown in rockwool. II. Fruit quality. Journal of Horticultural Science 68: 791-795.

Buriol, G.A.; Streck, N.A.; Petry, C.; Schneider, F.M. 1995. Solar radiation transmissivity through low density polyethylene used in greenhouses. Ciência Rural 25: 1-4 (in Portuguese, with abstract in English).

Callejón-Ferre, A.J.; Manzano-Agugliaro, F.; Díaz-Pérez, M.; Carreño-Ortega, A.; Pérez-Alonso, J. 2009. Effect of shading with aluminised screens on fruit production and quality in tomato (Solanum lycopersicum L.) under greenhouses conditions. Spanish Journal of Agricultural Research 7: 41-49.

Callejón-Ferre, A.J.; Carreño-Ortega, A.; Sánchez-Hermosilla, J.; Pérez-Alonso, J. 2010. Environmental impact of an agricultural solid waste disposal and transformation plant in the Province of Almería (Spain). Informes de la Construccion 62: 79-93 (in Spanish, with abstract in English).

Callejón-Ferre, A.J.; Velázquez-Martí, B.; López-Martínez, J.A.; Manzano-Agugliaro, F. 2011. Greenhouse crop residues: energy potential and models for the prediction of their higher heating value. Renewable and Sustainable Energy Reviews 15: 948-955.
Camacho-Ferre, F.; Montoya-García, M.E.; Benavides Gómez, C. 1998. Legislation on the Cultivation and Preparation of Fresh Horticultural Produce. Camponix Press, Níjar, Almería, Spain (in Spanish).

Castilla, N. 2005. Plastic Greenhouses: Technology and Management. Mundi-Prensa, Madrid, Spain (in Spanish).

Cockshull, K.E.; Graves, C.J.; Cave, C.R.J. 1992. The influence of shaing on yield of glasshouse tomatoes. Journal of Horticultural Science 67: 11-24.

DOCE. Regulation $\mathrm{n}^{\circ} 717$, of 11 April, that modified the Regulation $\mathrm{n}^{\circ} 790 / 2000$ of the Commission (DOCE L 95 of $15^{\text {th }}$ April), laying down the rules for the marketing of tomatoes. Official Journal of the European Community L 100, 11/04/2001.

Kittas, C.; Katsoulas, N.; Baille, A. 2003. Influence of aluminized thermal screens on greenhouse microclimate and night transpiration. Acta Horticulturae 614: 387-392.

Lorenzo, P.; García, M.L.; Sánchez-Guerrero, M.C.; Medrano, E.; Caparros, I.; Giménez, M. 2006. Influence of mobile shading on yield, crop transpiration and water use efficiency. Acta Horticulturae 719: 471-478.

Marcelis, L.F.M.; Broekhuijsen, A.G.M.; Meinen, E.; Nijs, E.M.F.M.; Raaphorst, M.G.M. 2006. Quantification of the growth response to light quantity of greenhouse grown crops. Acta Horticulturae 711: 97-103.

Medrano, E.; Lorenzo, P.; Sánchez-Guerrero, M.C.; García, M.L.; Caparrós, I.; Coelho, G.; Giménez, M. 2005. Water and nutrient use efficiency of a tomato crop as affected by two refrigeration methods: external mobile shading and fog system. Acta Horticulturae 697: 463-467.

Newton, P.; Sahraoui, R.; Economakis, C. 1999. The influence of air temperature on truss weight of tomatoes. Acta Horticulturae 507: 43-49.

Papadopoulos, A.P.; Pararajasingham, S. 1997. The influence of plant spacing on light and use in greenhouse tomato (Lycopersicon sculentum Mill) A review. Scientia Horticulturae 69: 1-29.

Petersen, K.K.; Willumsen, J.; Kaach, K. 1998. Composition and taste of tomato as affected by increased salinity and different salinity sources. Journal of Horticultural Science and Biotechnology 73: 205-215.

Varun; Bhat, I.K.; Prakash, R. 2009. LCA of renewable energy for electricity generation systems: a review. Renewable and Sustainable Energy Reviews 13: 1067-1073. 